\title{
PENGAMBILAN KEPUTUSAN PASIEN UNTUK MEMILIH RUMAH SAKIT
}

\author{
Ebial Fitri Br Ginting \\ ebyalfitriginting@gmail.com
}

\section{LATAR BELAKANG}

Adanya tuntutan masyarakat yang sangat tinggi terhadap kualitas pelayanan kesehatan. Sebagian pasien memutuskan untuk kembali berkunjung ke rumah sakit salah satunya ditentukan oleh kualitas pelayanan keperawatan.Rumah Sakit merupakan institusi pelayanan kesehatan yang menyelenggarakan pelayanan kesehatan perorangan secara paripurna yang menyediakan pelayanan rawat inap, rawat jalan, dan gawat darurat.

Pelayanan kesehatan yang diberikan oleh rumah sakit bersifat holistik atau menyeluruh mulai dari pencegahan, penyembuhan hingga pemulihan penyakit.Sejalan dengan semakin meningkatnya tuntutan masyarakat terhadap pelayanan medis menyebabkan masyarakat menjadi lebih selektif dalam memilih jasa pelayanan dari suatu rumah sakit.Perubahan tersebut disebabkan pulaoleh makin meningkatnya pendidikan dan keadaan sosial ekonomi masyarakat yang menimbulkan adanya kecenderungan di masyarakat untuk menuntut pelayanan rumah sakit yang lebih baik dan berkualitas.

Kualitas rumah sakit merupakan tolak ukur jasa pelayanan kesehatan. Bila suatu rumah sakit telah berhasil memberikan pelayanan kesehatan dengan baik sehingga memberikan kepuasan kepada kliennya, itu berarti rumah sakit tersebut telah memiliki kualitas yang baik. Dalam rangka tetap menjaga kualitas rumah sakit yang dapat bersaing, maka suatu rumah sakit haruslah bermutu dan harus sesuai dengan kriteria kebutuhan masyarakat. Pasien rawat inap memerlukan waktu perawatan, keterlibatan dokter dan perawat, serta penggunaan fasilitas rumah sakit yang lebih banyak, sehingga kualitas layanan dirasakan lebih penting. Dokter merupakan elemen rumah sakit yang paling besar peranannya. 
Sebuah rumah sakit yang banyak pasiennya, biasanya identik dengan dokter yang baik dan infrastruktur yang lengkap. Tidak heran, karena pasien datang ke rumah sakit untuk berobat. Pada bagian rawat inap, elemen kedua yang penting adalah perawat. Perhatian dan keahlian perawat sangat diperlukan sangat dibutuhkan selama pasien tinggal di rumah sakit (Ratnamiasih, 2013). Menurut peraturan Menteri Kesehatan Tahun 1998 No.159/Menkes/Kes II/1998 Bab II pasal 3 dinyatakan :

1. Rumah sakit dapat dimiliki dan diselenggarakan oleh pemerintah atau swasta.

2. Rumah sakit pemerintah dimiliki dan diselenggarakan oleh :

a. Departemen Kesehatan

b. Pemerintah Daerah

c. ABRI

d. Badan Usaha Milik Negara

3. Rumah sakit swasta dimiliki dan diselenggarakan oleh :

a. Yayasan

b. Badan hukum lain yang bersfat sosial.

Menurut Kepmenkes Bo.986/MENKES/SKXI/1992 tentang pedoman organisasi rumah sakit umum,maka rumah sakit umum di Indonesia dapat dikelompokkan menjadi beberapa kelas berdasarkan pada pembagian tersebut yang meliputi :

a. Rumah Sakit Umum Kelas A adalah rumah sakit yang mempunyai fasilitas dan kemampuan b. Rumah Sakit Umum Kelas B adalah rumah sakit yang mempunyai fasilitas dan kemampuan pelayanan medik

sekurang-kurangnya 11 spesialistik dan subspesialistik terbatas.

c. Rumah Sakit Umum Kelas C adalah rumah sakit umum yang mempunyai fasilitas dan kemampuan pelayanan medik spesialistik dasar. 
d. Rumah Sakit Umum Kelas D adalah adalah rumah sakit umum yang mempunyai fasilitas dan kemampuan pelayanan medik dasar.

\section{METODE}

Metode yang digunakan adalah metode kualitatif dimana maksudnya dengan cara mengumpulkan sebanyak-banyaknya data untuk dianalisis. Yaitu dengan Literature review ini dengan menganalisis yang berfokus pada kompetensi kemampuan berpikir dalam praktik keperawatan. Adapun tinjauan literatur yang digunakan seperti buku teks, buku referensi, jurnal, dan google scholar. Dengan kata kunci pengambilan keputusan pasien untuk memilih rumah sakit. Dan yang digunakan adalah 14 literatur yang diterbitkan 10 tahun terakhir.

\section{HASIL}

Saat Anda menghadapi suatu masalah dan perlu mengambil suatu tindakan di antara beberapa alternative pilihan, maka Anda sedang berada dalam proses membuat keputusan. Pengambilan keputusan adalah suatu produk dari pemikiran kritis yang bertujuan untuk memecahkan masalah. Sebagai contoh, pengambilan keputusan terjadi saat seseorang memilih penyedia layanan kesehatan. Untuk membuat keputusan, seseorang harus mendefinisikan adanya masalah atau situasi ( perlu pusat pelayanankesehatan dengan pelayanan tertentu), dan menganalisis seluruh pilihan yang ada ( mempertimbangkan pusat pelayanan kesehatan yang telah direkomendasikan atau yang terdekat dari rumah). Orang tersebut harustiap pilihan dengan criteria yang kita punya (pengalaman, keramahan, dan reputasi), mencoba pilihan yang mungkin memeriksa pro dan kontra memilih satu pusat kesehatan di antara yang lain), dan membuat keputusan akhir.

Walaupun sebuah kriteria mengikuti langkah-langkah tertentu, pengambilan keputusan dapat melangkah mundur dan maju dalam mempertimbangkan semua kriteria. Pengambilan keputusan mengarah kepada pengambilan kesimpulan yang didukung oleh bukti dan alasan. Contoh pengambilan keputusan pada situasi klinis meliputi keputusan untuk memilih balutan yang sesuai untuk membalut luka bekas operasi klien atau memilih pendekatan terbaik untuk mengajarkan keluarga bagaimana membantu klien sepulangnya dari rumah sakit setelah terkena stroke. Anda akan belajar untuk membuat keputusan sesuai dengan situasi klinis yang ada dan menerapkan masing-masing langkah yang telah dijelaskan di atas. 
Pada suatu situasi klinis, penentuan diagnosis dimulai segera setelah Anda menerima informasi mengenai klien. Penentuan diagnosis merupakan proses untuk menentukan status kesehatan setelah menganalisis perilaku, tanda, dan gejala yang ada pada klien. Penentuan diagnosis dimulai pada saat Anda berinteraksi dengan klien atau pada saat Anda melakukan observasi fisik atau perilaku. Perawat yang mahir akan melihat keadaan klien yang berhubungan dengan penentuan diagnosis ( contoh: mengenali klien yang mengalami penurunan ketajaman penglihatan dan riwayat diabetes mellitus memiliki hubungan dengan kadar gula darah yang tidak terkontrol), observasi pola dan tema ( contoh: gejala meliputi kelemahan, sakit kepala, rasa lapar, dan gangguan penglihatan yang menandakan hipoglikemia) (Ferrario,2004). Informasi yang diperoleh dan dianalisis kemudian digunakan untuk menentukan diagnosis klien. Penentuan diagnosis menyediakan perspektif yang jelas tentang status kesehatan klien. Perawat tidak membuat diagnosis penyakit, melainkan menganalisis, mengamati dengan ketat, dan membandingkan gejala dan tanda penyakit yang biasanya dialami oleh klien dengan diagnosis penyakit tertentu. Tipe penentuan diagnosis ini membantu dokter atau penyedia pelayanan kesehatan untuk mendeteksi masalah lebih cepat dan memerikan terapi yang tepat.

\section{PEMBAHASAN}

Menurut analisis peneliti, kehandalan perawat tidak berhubungan dengan proses pengambilan keputusan pasien untuk memilih Rumah Sakit Muhammadiyah Palembang dikarenakan masih ada responden yang menilai bahwa perawat kurang profesional, tidak menepati janji yang telah diberikan pada pasien misalnya saat pasien mengeluh nyeri perawat mengatakan akan menghubungi dokterDPJP tetapi perawat tersebut tidak memberikan informasi kembali terkait sudah atau belum DPJP tersebut dihubungi, perawat bersikap kurang ramah, perawat tidak akurat dalam mencatat datadata pasien dan kurang teliti dalam melakukan tindakan keperawatan. Lebih dari separuh responden tetap akan memilih Rumah Sakit Muhammadiyah Palembang jika suatu saat responden / keluarga responden membutuhkan layanan kesehatan dikarenakan Rumah Sakit Muhammadiyah Palembang merupakan rumah sakit yang memberikan pelayanan yang islami (bernuansa islam) dan Rumah Sakit Muhammadiyah Palembang menerima jaminan kesehatan BPJS maupun asuransi lain.

\section{Hubungan Umur terhadap Keputusan Dalam Memilih}


Hasil penelitian dari variabel umur sebagian besar pasien pada kelompok umur 18-50 tahun menyatakan tidak memilih untuk rawat inap di RS Putri Hijau. Kemudian untuk kelompok umur >51 tahun sebagia besar juga tidak memilih untuk rawat inap di RS Putri Hijau.Hasil uji statistik pada hasil menunjukkan bahwa bahwa variabel umurtidak mempunyai hubungan yang siginifikan terhadap keputusan pasien dalam memilih rawat inap di RS Putri Hijau.Penelitian ini sesuai dengan penelitian yang dilakukan oleh Fauzia (2014) dengan judul Faktor-Faktor yang Berhubungan dengan Keputusan Pemilihan Tempat Persalinan Pasien Poliklinik Kandungan dan Kebidanan di Rumah Sakit Ibu dan Anak Kemang Medical Care bahwa pada hasil penelitiannya Hasil uji statistikmenunjukan bahwa tidak ada hubungan yang signifikan antara usia dengan keputusan pemilihan tempat persalinan di RSIA.

\section{Hubungan Pekerjaan terhadap Keputusan Dalam Memilih}

Hasil penelitian dari variabel Pekerjaansebagian besar pasien pada kelompok umur tidak bekerja menyatakan tidak memilih untuk rawat inap di RS Putri Hijau. Kemudian untuk kelompok bekerja sebagian besar juga tidak memilih untuk rawat inap di RS Putri Hijau. Hasil uji statistik pada hasil menunjukkan bahwa bahwa variabel pekerjaantidak mempunyai hubungan yang siginifikan terhadap keputusan pasien dalam memilih rawat inap di RS Putri HijauPola konsumsi seseorang juga dipengaruhi oleh pekerjaannya. Kelompok pekerjaandan jabatan mempunyai kecendrunganminattertentu terhadap suatu produk barang dan jasa.Jenis Pekerjaan bisa mempengaruhi seseorangdalam pemilihan tempat pelayanan kesehatan karena pekerjaanberhubungan dengan pendapatan Namun,tidakselamanya pekerjaan mempengaruhi dalammemilih tempat pelayanan kesehatan, walaupun jenis pekerjaanseseorang berbeda tetapi harapan mereka akankesehatan sangat tinggi, untuk mendapatkanpelayanankesehatan yang terbaik. Sehingga tidakada pengaruh jenis pekerjaan terhadap pemanfaatan pelayanan kesehatan (Nurlinda dan Suprianto,2014).Pada hasil penelitian ini pekerjaan bukan salah satu faktor pasien melakukan keputusan dalam memilih rawat inap. Karena pada kedua kelompok baik yang bekerja dan tidak bekerja keduanya hampir sama besar untuk tidak memilih rumah rawat inap di RS Putri Hijau. Perbedaan pekerjaan tidak menjadi faktor seseorangdalam memilih pelayanan yang memiliki keamanandan kenyamanan.Oleh karena itu, dalam upaya untuk meningkatkan pemanfaatan bed rawat inap di rumah sakit faktor pekerjaan bukanlah dasar utama, namun demikian tetap harus diperhatikan karena menyangkut hal lain seperti gaya hidup selain pekerjaan itu sendiri. Dengan menjadi karyawan akan terkait dengan jaminan kesehatan walaupun tidak semua karyawan mendapatkan jaminan kesehatan gratis dari instansinya, hal ini berarti ada kaitan dengan penanggung biaya yang mana penanggung biaya akan menentukan tempat sebagai rujukan dalam pelayanan kesehatan.

\section{Hubungan Pendapatan terhadap Keputusan Dalam Memilih}

Hasil penelitian dari variabel Pendapatansebagian besar pasien pada kelompok pendapatan < UMR menyatakan tidak memilih untuk rawat inap di RS Putri Hijau. Kemudian untuk kelompok pendapatan> UMR sebagian besar juga tidak memilih untuk rawat inap di RS 
Putri Hijau. Hasil uji statistik pada hasil menunjukkan bahwa bahwa variabel pendapatan tidak mempunyai hubungan yang siginifikan terhadap keputusan pasien dalam memilih rawat inap di RS Putri Hijau.Penelitian ini sesuai dengan penelitian yang dilakukan oleh Nurlinda dan Supriyanto (2014) yang berjudul pengaruh faktorkarakteristik individu, psikologi dan sosial terhadaptempat persalinan di fasilitas kesehatan bahwa pada hasil penelitiannya Berdasarkan uji statistik pendapatan tidak berpengaruhterhadap pemanfaatan tempat bersalin.

\section{PENUTUP}

Untuk berpikir cerdas seorang perawat harus mengembangkan cara berpikir kritis dalam menghadapi setiap masalah dan pengalaman baru yang menyangkut pasien dengan memiliki karakteristik percaya diri, berpikir mendalam, keadilan, tanggung jawab dan akuntabilitas, mengambil resiko, disiplin, kegigihan, kreatif, rasa ingin tahu, mempunyai daya intelektual danintegritas, dan rendah hati, mempunyai sifat fleksibeldi mana karakteristik tersebut dapat dilihat dari sikap dalam memberikan asuhan keperawatan keterlibatan, kedewasaan untuk mengontrol emosi dan inovasi. Seorang perawat yang menerapkan pemikiran kritis dalam bekerja akan fokus terhadap penyelesaian masalah dan membuat keputusan, serta tidak akan membuat keputusan yang terburu-buru, ceroboh dan tidak merugikan klien. Perawat harus menerapkan pemikiran kritis tersebut agar dalam mengambil keputusan klinis tidak merugikan orang lain.

1.Untuk mempertahankan dan memberikan pelayanan terbaik, sebaiknya rumah sakit terus melakukan peningkatan mengenai ketersediaan fasilitas, jenis, atau variasi jasa pelayanan kesehatan yang lebih lengkap.

2. faktor-faktor yang mempengaruhi keputusan pasien dalam pemilihan rumah sakit dapat diperluas dengan melakukan penelitian yang sama pada rumah sakit lain dan membandingkan hasilnya. Sehingga dapat diketahui hasil secara umum, tidak hanya pada satu rumah sakit saja. 


\section{DAFTAR PUSTAKA}

Simamora, R. H. (2019). Menjadiperawat yang: CIH'HUY. Surakarta: Kekata Publisher.

Simamora,

R.

$\mathrm{H}$. (2005). HubunganPersepsiPerawatPelaksanaTerhadapPenerapanFungsiPengorganisasian Yang DilakukanOlehKepalaRuanganDenganKinerjanyaDiruangRawatInap RSUD Koja Jakarta Utara (Doctoral dissertation, Tesis FIK UI, Tidakdipublikasikan).

Dina Mariana.(2019). Hubungan kualitas pelayanan keperawatan rawat inap dengan proses pengambilan keputusan pasien untuk memilih rumah sakit. Jurnal Ilmiah Multi Science Kesehatan. Volume 10, Juni 2019, Nomor 2

SONIA.(2018). Analisis yang berhubungan dengan keputusan pasien dalam memilih ruang rawat inap di rumah sakit putri hijau tahun 2017. Jurnal ilmiah simatek. Vol. 2, No. 2, April 2018

Dwi Purwati, Retno Koeswandari. (2015). Hubungan mutu pelayanan dengan pengambilan keputusan pasien terhadapa penggunaan jasa di rsu at-turots al- islamy Yogyakarta

Walansendow, V1. 2017. Hubungan Antara Sikap dan Teknik Komunikasi Terapeutik Perawat Dengan Kepuasan Pasien Rawat Inap Di Ruang Eunike Rsu Gmim Kalooran Amurang. Ejournal Keperawatan, 5(1), 2-3

Hilyah Magdalena.(2017). Analisis faktor pendukung pengambilan keputusan memilih rumah sakit rujukan di Bangka Belitung dengan analitycal hierarchy process.Joural foundation of informatics. Vol 2, No.2, November 2017

Purwaningsih, D.F. 2015. Strategi Meningkatkan Perilaku Caring Perawat Dalam Mutu Pelayanan Keperawatan. Jurnal Management Keperawatan. 3(1), 1-6

Nurfitria, Ningsih. 2015. Hubungan Asuhan Keperawatan dengan Pengambilan Keputusan Memilih Pelayanan Rawat Inap di RSUD Panembahan Senopati.

Nusawakan, A.W. (2017). Faktor yang mempengaruhi pengambilan keputusan dalam penggunaan layanan kesehatan pada wilayah kerja puskesmas tawiri. Vol 6 No 2 (2017)

Nila, Vicky. 2012. Faktor-faktor Yang Mempengaruhi Pengambilan Keputusan Masyarakat Untuk Memilih Jasa Pelayanan Kesehatan di Rumah Sakit PKU Muhammadiyah Simo Kabupaten Boyolali. Naskah publikasi 
Utama, S. (2005). Memahami kepusaan pasien Rumah Sakit. Jurnal Manajemen Kesehatan 09 (1), 1-7. 